9alabra Clave • ISSN 0122-8285 • Volumen 13 Número 1 • Junio de 2010

\title{
Colombian Media in the XXI Century: The Re-conquest by Foreign Investment
}

\section{Los medios de comunicación colombianos en el siglo XXI: La reconquista por la inversión extranjera}

\author{
Germán Arango-Forero ${ }^{1}$ \\ María Fernanda Arango ${ }^{2}$ \\ Laura Llaña ${ }^{2}$ \\ María Carolina Serrano ${ }^{3}$
}

\begin{abstract}
This paper summarizes and examines the more relevant financial investments, mergers and acquisitions carried out in the Colombian media market by major international groups during the first decade of the 21st century. In a highly unprecedented environment and within a period of only ten years, an important share of Colombia's leading media companies passed into the hands of foreign firms that remain attracted to the country, given the size of the market, the potential for growth in the different sectors and the policies on foreign direct investment being stimulated and protected by the national government in the field of media content distribution and telecommunication service delivery. The Spanish groups Planeta, Prisa and Telefónica, and Telmex from Mexico have become the main players in this phenomenon, which is known as The Re-conquest.
\end{abstract}

Key words: Colombia, foreign investment, media markets, telecommunications, multinational communication enterprises.

\begin{abstract}
Resumen
Este trabajo resume y analiza las inversiones financieras más relevantes, las fusiones y adquisiciones realizadas en el mercado de medios de comunicación colombianos por los principales grupos internacionales durante la primera década del siglo XXI. En un entorno sin precedentes y en un plazo de sólo diez años, una parte importante de las empresas de comunicación líderes en Colombia pasó a manos de empresas extranjeras que siguen atraídas por el país, dado el tamaño del mercado, el potencial de crecimiento en los distintos sectores y las políticas sobre inversión extranjera directa, que han sido estimuladas y protegidas por el gobierno nacional en el ámbito de los medios de distribución de contenidos y la prestación de servicios de telecomunicaciones. Los grupos españoles Planeta, Prisa y Telefónica, y Telmex de México se han convertido en los principales protagonistas de este fenómeno, conocido como La Reconquista.
\end{abstract}

Palabras clave: Colombia, inversión extranjera, mercados de los medios de comunicación, telecomunicaciones, empresas multinacionales de comunicación.

1 PhD Student. Associate professor. School of Communication. La Sabana University, Colombia. german.arango@unisabana.edu.co

2 Audiovisual and Multimedia Communication student. School of Communication. La Sabana University. mariarangok@gmail.com; laura_llana88@hotmail.com

3 Chief of Internationalization and communication. International school of economic and administrative sciences. La Sabana University.

Recibido: 01/02/10

Aceptado: 27/04/10 


\section{An Overview of Foreign Direct Investment (FDI) in Colombia}

Globalization instituted a new framework for the international economy; one characterized by a reduction in barriers the world over. This has stimulated foreign investment in countries where it otherwise would be unimaginable, facilitating the creation of common markets and promoting the expansion of multinational enterprises.

Foreign direct investment (FDI), as one of the two ways of investing in a foreign country (the other being stock market investments), is defined by the International Monetary Fund as "the category of international investment that reflects the objective of a resident entity in one economy to obtain a lasting interest in an enterprise resident in another economy (...) The lasting interest implies the existence of a long-term relationship between the direct investor and the enterprise and a significant degree of influence by the investor in the management of the enterprise" (Balance of Payments Manual, 1994, p. 86)

According to the United Nations Conference on Trade and Development (UNCTAD), foreign direct investment "has the potential to generate employment, increase productivity, specialized knowledge and technology transference, increase exports, and -in the long term- to contribute to economic development in developing countries" (Inversión Extranjera Directa (IED, 2010, 1). The Conference states that FDI is the most significant external financing source for developing countries and now accounts for up to a third of their gross domestic product (GDP), as opposed to $10 \%$ in 1980 .

In 1990, after decades of protectionist policies based on import substitution, which saturated national markets with local production and created a situation where supply exceeded demand, Co- lombia's President, César Gaviria Trujillo, decided to open up the economy through a long-term economic strategy designed to stimulate the country's growth. The respective regulations became a chapter in the 1991 Colombian Constitution.

This effort to liberalize the economy modified the import system through tariff reductions, financial deregulation, privatization of stateowned enterprises, and the adoption of a more liberal foreign exchange rate. In turn, these measures eased import restrictions and opened up most sectors to foreign investment, although agricultural products remained protected. Traditional exports such as coffee, petroleum and coal were displaced somewhat by non-traditional exports such as textiles, food, printing services, publishing services, chemicals and clothing, among other goods of industrial origin. The only activities closed to foreign direct investment are national defense and security, and hazardous waste disposal.

The same occurred in the rest of South America and throughout Latin America's developing countries in general: "Privatization of many state-owned enterprises, as well as the adoption of certain macroeconomic policies, an improvement in infrastructure and regional integration (e.g. MERCOSUR) explained much of the growth... Although growth was constant during the periods in question, it is important to highlight the fact that the Latin American countries are very susceptible to special circumstances that can change the flow of foreign direct investment during different periods. Political instability, economic crises, and insecurity (e.g. as in the case of Colombia and other countries with guerrilla groups) have made Latin America an unpredictable field for some multinational enterprises" (Tellez, Bohórquez \& Godoy, 2009, p. 106).

Colombian law on FDI is mixed, as it combines private and public law with national and international legislation on specific aspects with regard 
Decree 2080 is based on the principle of equality; in other words, foreign investment in Colombia is treated the same as investments made by Colombian nationals abroad.

to labor, commerce and taxes. In 2002, the Colombian government issued Decree 2080, which outlines the General Investment Regime for foreign capital in Colombia and Colombian capital abroad. Decree 2080 is based on the principle of equality; in other words, foreign investment in Colombia is treated the same as investments made by Colombian nationals abroad.

Law 963, developed in 2005, focuses on generating an environment of trust, confidence and stable legal grounds for international investors. It allows foreign investors to pursue contracts with the government, under the guarantee that the conditions applicable to FDI, when the contract is signed, shall remain in effect for 20 years thereafter.

Free trade zones are another strategy used to encourage foreign investment. They are geographically limited areas where industrial goods and services or commercial activities may be developed under special tariff, trade and customs arrangements, the main one being that every product or service originating in a free trade zone is regarded as originating outside Colombian territory as far as import or export duties are concerned.

The Andean and Colombian parameters relevant to the Group of Three (Colombia, México, Venezuela) and the norms on Bilateral Investment Treaties and Free Trade Treaties (especially with the United States) constitute an international framework that favors FDI.

"An adequate environment for enterprise, in addition to the permanence of transnational enterprises in Colombia and their intention to develop new projects, has become the best promotion for the country and shows why it is one of the few economies in Latin America that has experienced a dynamic rate of growth in FDI" (Universidad del Rosario, 2006, p. 8).

According to the Doing Business Global 2009 Report, Colombia was the only country in Latin America to be among the world's Top 10 Reformers for the second year in row. "This is in recognition of the easing of regulations to facilitate growth in business activity and also sets a trend towards facilitation and improvement of the business environment" (Latin Trade Magazine, 2009, p. 52).

By February 15, 2010, FDI already had exceeded the Colombian government's expectations, having reached USD $\$ 1,028$ million. This is an increase of $1.9 \%$ compared to 2009 (Portafolio, February 10, 2010) and is very important, considering the economic recession in 2009 had a visible impact on FDI around the world. In fact, FDI in Colombia was down $10.4 \%,{ }^{4}$ while the

\section{Graphic 1 Colombia's FDI flow COUNTRY OF ORIGIN \% of participation January - September 2009}

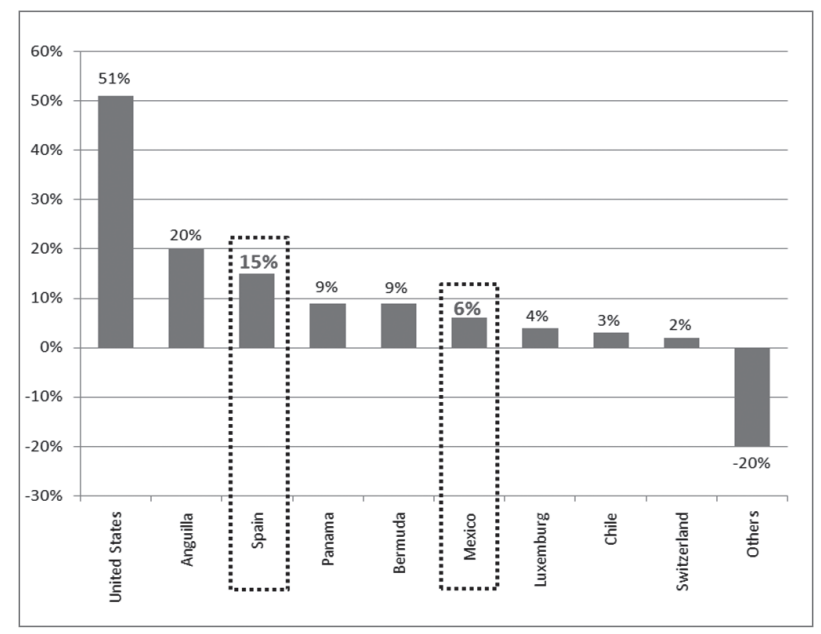

4 FDI in Colombia reached USD $\$ 7.201$ billion, which is $32 \%$ less compared to the incoming flow of investment in 2008. The only sector to see an increase in investment was mining. (El Tiempo, 2010, p. 1-9) 
decline worldwide was around 44\% (Caracol Radio, December 10, 2009).

According to data from the Central Bank of Colombia, most FDI in the country comes from the United States, Anguilla ${ }^{5}$ and Spain (See Graph 1 ) and is destined largely for mining (including coal) and the petroleum sector (See Graph 2). Between January and September 2009, foreign direct investment in the Colombian economy came to USD\$6.446 billion (Report on FDI in Colombia according to payments and exchange balances, 2010, 2009, pp. 3-4).

\section{Graphic 2 Colombia's FDI flow MAIN ECONOMIC SECTORS $\%$ of participation January - September 2009}

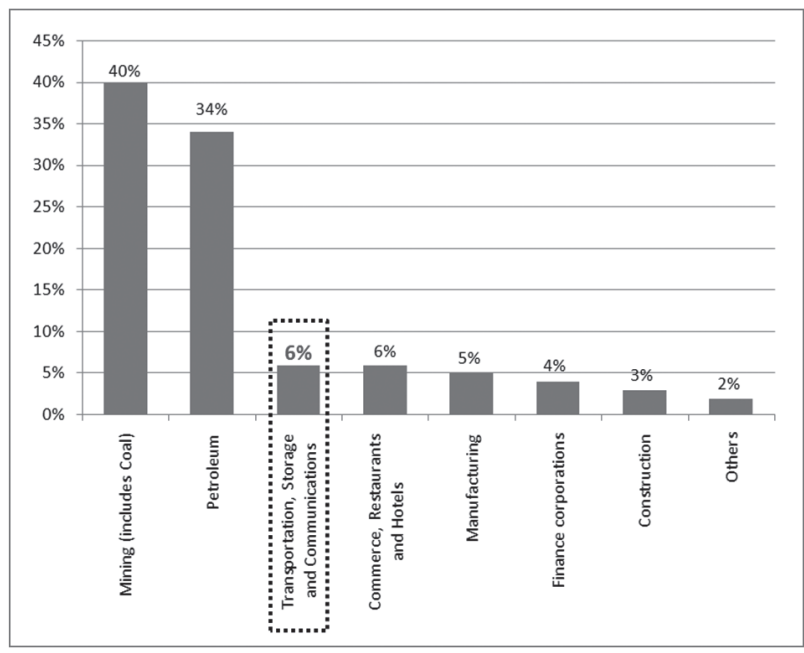

\section{FDI from the USA, Spain and Mexico}

Although the largest investment flow comes from the United States of America, FDI from Spain and Mexico is important as well, not only because of its accelerated growth, but also due to its huge impact on Colombian corporate dynamics, especially in the telecommunications

5 A British overseas territory located in the Caribbean, specifically in the Lesser Antilles. sector. Between 2003 and 2008, Spanish investment in Colombia came to USD $\$ 2$ billion; and, in 2008, Mexican FDI in the country rose to more than USD\$300 million (Semana, May 2, 2009).

Mexican investment in Colombia has been primarily in cement (CEMEX), communications (América Móvil, Telmex), food production (Bimbo, Gruma S.A., FEMSA) and chemicals (Mexichem). In 2009, Colombia displaced Venezuela as the second destination for Mexican investment in Latin America. Between 2007 and 2009, Mexican FDI in Colombia grew 12.7\% (Milenio, January 2, 2010). According to Proexport Colombia, Mexican investment during the first quarter of the year came to USD $\$ 64.5$ million, which represents an increase of $29 \%$ compared to the same period in 2008 (Informe de Exportaciones, Inversión Extranjera y Turismo México, 2009, p. 11)

A look at Mexico's FDI in Colombia by economic sector shows it is concentrated mostly in telephone and telecommunication networks $(63.2 \%)$, followed by cement and reinforced concrete $(11.49 \%)$, beverages $(9.25 \%)$, chemical products $(6.39 \%)$, plastics $(4.68 \%)$, and machinery and equipment (1.86\%) (Milenio, January 2, 2010).

Spanish investment in Colombia is now evident in more than 120 corporations, having an impact on almost every sector of the economy: specifically in the finance and banking sector with BBVA, Banco Santander and Mapfre; in communication and telecommunications with Telefónica, Planeta and Prisa, not to mention Spanish ownership of $50+1$ of the shares in Telecom; Eulen in general services; GMO in optics; Atento (part of Telefónica ), Digitex, Telemark, Emergia Customer Care and Avanza BPO in call centers and contact center services; Zara and Mango in the textile sector; Fronpeca in hotel construction, along with NH Hotels; Colsánitas in health; Gas Natural in public utilities, and Fenosa Union in the hydroelectric sector. 
This influence involves the expansion of existing companies and the entry of new mediumsized enterprises, encouraged by the success of the pioneers.

According to Colombia's Ministry of Commerce, Industry and Tourism, the impact of FDI in telecommunications, an area that represents $41 \%$ of the transportation and communication sector, which accounts for $8 \%$ of the country's GDP, has been particularly significant during the last 10 years (Industria BPOEO en Colombia, 2009, p. 9).

\section{FDI Impact on Colombian Media Markets}

Due to the impact of FDI on the Colombian economy, a new commercial media environment has been consolidated within the country by the end of the first decade of the 21st century. One of the most relevant economic factors deals with the growing and prominent penetration of foreign investors and the acquisition of important telecommunication service and media content distribution companies by international media groups. As indicated earlier, most of this foreign investment has come from Spain, which is why the phenomenon is referred to as "La Reconquista", which is the Spanish and Portuguese term for re-conquest.

Why is it called the re-conquest? Two centuries after Colombia declared its independence from Spain on July 20, 1810, the arrival of foreign companies as major shareholders of important national media firms reflects a broader trend among national media conglomerates to develop mergers and alliances as a way to expand their coverage and influence (Arango et al., 2009, p. 64).

This new phenomenon with respect to the Colombian media is not an isolated occurrence within the region. As illustrated earlier, the last decade of the $20^{\text {th }}$ century witnessed a profound neoliberal tendency in terms of Latin American politics and the economy. Open market policies, freedom to conduct financial mergers and acquisitions, and privatization of certain public utilities, including telecommunications, were quite common among the developing nations. Also, new foreign actors who introduced new technological services (such as mobile telephone, Internet, and cable and satellite television service) played an extremely important role in the expansion of new media companies and telecommunication services under an oligopolistic market structure (Sinclair, 2000; Herman and McChesney, 1997).

Two decades later, the final result seems to be a highly unbalanced map of the region, with Mexico, Brazil and Argentina in first place, with consolidated media markets; Venezuela, Colombia and Chile in a stable and growing position; nations like Peru and Uruguay in a middle position; and small, poor countries like Paraguay, Bolivia and most of the Central American nations at the bottom of the list. This categorization deals directly with demographics, gross domestic product, personal income and the size and nature of media markets, among other factors (Mastrini and Becerra, 2007).

In a developing region with serious social inequities, free media such as open television and radio remain the most powerful in terms of penetration and coverage. Low-income sectors have very little access to paid media and new telecommunication services. Furthermore, it is important to bear in mind that new media literacy is limited among low-income sectors.

\section{The Size of the Colombian Media Market}

In the case of Colombia, $93.7 \%$ of households had a television set in 2005 (DANE). Nowadays, 
the television industry has reached a stable peak of $93.5 \%$ with respect to audience attention, while radio has $68.7 \%$, independent magazines $42 \%$, newspapers $33.9 \%$, Internet $30.3 \%$, newspapers and magazines $22.2 \%$, and movie theaters 5.3\% (ACIM-EGM 2009-II).

With regard to the size of the country, the Colombian media market can be considered one of the most populated in Latin America. According to the National Bureau of Statistics (DANE 2009) and the Economic Commission for Latin America and the Caribbean (ECLAC 2009), the Colombian population is the third largest in the region after Brazil and Mexico, and Colombia is the second largest Spanishspeaking nation, with more than 45 million inhabitants by the end of 2009. According to DANE projections, $78.5 \%$ of the Colombian population will be living in and around urban areas by the end of 2010 .

The numbers still show an attractive and potential market for telecommunications and media services that were in the hands of a few national entrepreneurs, even before the arrival of international investors.

Despite the size of the population and the quantity of potential readers, only two national daily newspapers printed in Bogotá, the nation's capital, compete for control of the national market. Nowadays, El Tiempo (Grupo Planeta) is still the leader. Its opponent, $E l E s$ pectador, the oldest newspaper in Colombia, was forced to become a weekly between August 2001 and May 2008, due to a serious financial crisis. In each of Colombia's other three major cities, only one daily newspaper leads the local and regional market: El Colombiano in Medellín; El País in Cali; and El Heraldo in Barranquilla. Smaller cities such as Bucaramanga, Manizales, Pereira, Cúcuta and Cartagena face a similar situation (Arango et al., 2009).
The numbers still show an

attractive and potential market for telecommunications and media services that were in the hands of a few national entrepreneurs, even before the arrival of international investors.

The magazine industry has grown steadily in Colombia, mostly during the last two decades. Between 2001 and 2006, the market increased at an average annual rate of $5.9 \%$. Casa Editorial El Tiempo, Publicaciones Semana and Editorial Televisa S.A. headed the competition in an oligopolistic environment (Research and Markets, 2010).

As for television, the country had only two nationwide commercial channels for over forty years. Both were owned by the state and broadcasted by private producers under a publicprivate arrangement. There was a third national public channel, mainly cultural and educational. Two private national channels were created in 1998: Caracol and RCN. Ten years later, Colombia had the same two national private channels (Caracol and $\mathrm{RCN}$ ), one national channel owned by the state and broadcasted by small private producers, two national public channels, one local private channel in Bogotá, eight regional public channels, 47 local non-profit frequencies, 915 community frequencies, 62 cable operators and two satellites companies (CNTV, 2008).

The Colombian television market has increased as well, with the highest penetration of paid television (cable or satellite) in the region. By September 2009, the average in terms of Latin American households with paid television was $39.9 \%$. In Colombia, it was $76 \%$ (67.5\% in the low-income bracket, $79.4 \%$ in the middle-income bracket and $90.1 \%$ in the high-income bracket). Argentina 
ranked second with $73 \%$ of households (LAMAC 2009). The proportion of paid television in Colombia increased from $55.7 \%$ to $78.2 \%$ between 1999 and 2009 (ACIM-EGM 2009-II).

The radio industry is the only one with a monopolistic competitive structure. However, two large national networks are still the most important: Cadena Radial Colombiana (Caracol, Prisa Group) and Radio Cadena Nacional (RCN). There are many local stations affiliated with these two major networks.

As for the consumption of electronic equipment, $93.1 \%$ of Colombian households in urban areas had a television set by the end of 2008, on average, $54.1 \%$ had a DVD player, $28.5 \%$ had a PC, $59,1 \%$ had a paid television subscription, and $16.4 \%$ had a dedicated Internet service provider (DANE 2009).

Internet services have grown during the past decade, but official statistics differ. According to the Asociación Colombiana de Investigación de Medios (Colombian Media Research Association), national coverage was $19.8 \%$ in 2006 and $30.3 \%$ by the end of 2009 (ACIM-EGM 2009-II). Nevertheless, a report by the Comisión de Regulación de Comunicaciones (Communications Regulatory Commission) says Internet use in Colombia peaked at $44.01 \%$ in September 2009 , with $86.9 \%$ broadband access, and ranked third in the region, after Chile and Argentina. In December 2008, Internet centers open to the general public remained number one in terms of access, with an average of $47.2 \%$, followed by households with 43.8\% (DANE 2009). Despite the growing numbers, Internet penetration in Colombia remains under $50 \%$. This reflects a challenging environment for continued growth at a stable rate.

With respect to mobile telephone service, there were 42,025 million active users by the end of
2009. This is according to the Asociación de la Industria Celular de Colombia (Colombian Mobile Telephone Industry Association) and represents $93 \%$ of the entire population. The penetration of mobile telephone service increased from $17.7 \%$ to $83.8 \%$ between 2003 and 2008, taking into account both urban and rural areas (DANE, 2009). The mobile telephone industry operates in an oligopolistic market. Comcel (America Móvil) is the leader, with $67 \%$ of the total market, followed by Movistar (Telefónica) with 22\% and Tigo (Millicom) with 11\%.

Despite the numbers, the mobile telephone market in Colombia remains largely that of a basic service provider (mainly voice and SMS). Comcel and Tigo launched third generation services in 2008 , but with a very limited spectrum in broadband mega hertz frequencies. New mobile services such as broadband Internet access, web TV, games and social networking require far more spectrum than is currently available in most Latin American countries (Roetter 2009, p. 20).

In 2009, the Colombian Congress approved Information and Telecommunications Technology Act No. 1341, which is an attempt to establish a fundamental framework for new public policy in the ICT sectors. Among others guarantees, the new law ensures an open competitive regimen, protection for users, investment promotion and technological neutrality.

It also determines government intervention in the ITC sectors to promote and guarantee open

The radio industry is the only one with a monopolistic competitive structure. However, two large national networks are still the most important: Cadena Radial Colombiana (Caracol, Prisa Group) and Radio Cadena Nacional (RCN). 
and loyal competition by avoiding dominantposition abuses. In other words, the new law promotes and protects all kinds of investment and strategic alliances, mainly for foreign investors and international groups who see Colombia as a developing market with potential for the introduction of new information and communication technology services.

\section{Foreign Investors in Main Media Content in Colombia}

One of the largest foreign investors in the Colombian media industry is Spain's Planeta Group. Founded in Barcelona in 1949, it specializes in the production of cultural, informative, educational and entertainment content for French and Spanish-speaking markets.

In 1966, Planeta opened its first subsidiaries in Mexico and Colombia, with Editorial Planeta Colombia S.A (a publishing company renamed Editorial Planeta de Agostini S.A. in 2001). In 2004, Planeta made a tentative offer to purchase the publishing company Editorial Norma, but the deal never took place.

In 2007, Colombia's leading media group, Casa Editorial El Tiempo (CEET), a traditional family media business owned by the Santos clan, decided to expand its brands and to welcome foreign investment. In a merger process, CEET accepted Planeta as its largest shareholder in what was to become the first commercial agreement that allowed the Spanish group to broaden its influence in the Colombian media market. The deal was finalized for an estimated USD

PRISA eventually withdrew from the bidding in December, saying the process was flawed and full of improvisation that undermined investor confidence on the project.
$\$ 338$ million (Dinero, August 3, 2007) and included $40 \%$ of CEET's local private television channel (Citytv). This is the largest amount of shares a foreign company may own in a Colombian commercial television channel.

As of that moment, Planeta's advertising revenue increased $20 \%$ and the revenue from all CEET products rose significantly compared to 2006. El Tiempo grew 12\%; the weeklies, $17.8 \%$; Hoy (a daily paper), $55.7 \%$; the magazines, $43 \%$; Citytv, $19 \%$ in audience and $23 \%$ in advertising; and the 14 websites, $160 \%$ in revenue, $55 \%$ in unique users and $39 \%$ in view pages (El Tiempo, March, 2008).

Planeta also made important investments in El Círculo de Lectores, Intermedio Editores and Printer Colombia (Sierra, September 18, 2007). As a result of this alliance, it now has three media firms in Colombia: Editorial Planeta Colombia S.A, Editorial Planeta de Agostini S.A, and Casa Editorial El Tiempo (CEET) (See Graph 3). In 2008, Planeta and CEET launched a new advertising marketer known as Media 24, which caters to request from customers and advertisers via its media throughout the country (Portafolio, June 11, 2008).

In 2010, Planeta hopes to make a substantial capital investment by acquiring the license for Colombia's third private national television channel. Through Media 24, it plans to develop partnerships that will enable it to participate in international advertising campaigns.

There is also the PRISA Group, which is devoted to Spanish-language media with a focus on education, information and entertainment. Since 1958, when the Santillana Publishing House was founded, and as of 1985, when PRISA became the controlling shareholder of the SER network, the group has established itself as one of the strongest and soundest media companies in Europe and America. 
Volumen 13 Número 1 • Junio de 2010

Since 1999, PRISA has been among the major media investment groups in Colombia. In September, it signed an agreement with Valores Bavaria, an important branch of the Colombian Santo Domingo Group, to create a holding company. Based on that agreement, Valores Bavaria sold $19 \%$ of Caracol Radio and transferred to the holding company its stations in other countries such as Chile, France and the United States, which were valued at USD \$ 7 million in all. Meanwhile, PRISA contributed USD \$ 30 million the new enterprise (USD \$ 7 million to pay for the Caracol Radio stations) and US \$ 28 million for 19\% of Caracol Radio. It spent USD \$ 58 million in all. At the time, both Valores Bavaria and PRISA each had a 50\% stake in the holding company (Rueda G., April 19, 2002).

During 2002, PRISA obtained $60 \%$ of Caracol Radio. This was the result of a clause in the 1999 "exit" or "price adjustment" agreement, whereby Valores Bavaria would set the conditions if, after three years, the company was valued at more than USD $\$ 70$ million by the investment banker Violy McCausland (a permanent advisor to the Santo Domingo Group). However, if it was valued at less than USD \$ 58 million, PRISA would set the conditions. Violy McCausland valued the company at USD \$ 26 million, based on its EBITDA, as applied during the last three years. Therefore, Caracol Radio is now owned entirely by the holding, which is $60 \%$ owned by PRISA and $40 \%$ by the Santo Domingo group (Ibid).

In 2005, Casa Editorial El Tiempo (CEET) and PRISA signed a working agreement to create the Latin Advertising Group (GLP-Colombia), which is the largest company in Colombia specializing in communications solutions tailored to the customer's. CEET and Prisa each have a $50 \%$ interest in GLP and its mission to open up new scenarios for advertisers to develop communication strategies successfully (El Tiempo, May 4, 2005).
With respect to companies that provide services and content to users in the telecommunications market, Colombia has a standing duopoly between two large foreign companies: America's Directv and Mexico's Telmex.

In 2008, following a call to tender bids on the license for a third private national television channel in Colombia, PRISA allied with GNM (National Media Group) to present an offer. GNM includes the newspapers El Colombiano in Medellín, El País in Cali, El Universal in Cartagena, Vanguardia Liberal in Bucaramanga and $\mathrm{La}$ República. In October 2009, the Cisneros Group in Venezuela, which also was bidding for the license, along with PRISA, called for suspension of the process due to a lack of legal certainty for investment. PRISA eventually withdrew from the bidding in December, saying the process was flawed and full of improvisation that undermined investor confidence on the project.

2009 was a year of debt and losses for PRISA. The group had a debt of USD \$ 3.4 million and was forced to sell its 20\% minority interest in Editorial Santillana, the Portuguese group Media Capital and the television platform Digital Plus. It also sold a large block of shares to Talos Partner, a subsidiary of IBN (In-Store Broadcasting), which retained a $1.08 \%$ stake in the group ( $E l$ Tiempo, August 24, 2009).

In 2010, PRISA will focus on paying off all of its debt. The group plans to close an important deal with Liberty Acquisition, which will add to the already agreed sale of assets (another USD \$ 1. 7 million). PRISA will reduce its debt to about USD \$ 4.09 million, which is equivalent to 4.5 times its expected EBITDA this year, leaving Liberty with 137 million shares and USD \$ 900 million in net cash operating expenses, excluding the redemptions they produce (Portafolio, March 5, 2010). 


\section{Foreign Investment in Telecommunications}

With respect to companies that provide services and content to users in the telecommunications market, Colombia has a standing duopoly between two large foreign companies: America's Directv and Mexico's Telmex.

Directv, a satellite television service provider, offers all types of content through more than 200 channels, providing cutting-edge digital technology and high quality to more than 30 million customers in the U.S. and Latin America. Since the advent of HD TV, Directv has led the use of this new technology.

Founded in 1994, Directv entered the Latin America market with 1.3 million subscribers. In Colombia, it was finally authorized to enter the market after numerous disputes with CNTV over costs related to DHT (satellite signal decoder), in addition to the introduction of Señal Colombia (a public channel) to its programming in 1996 and a payment of USD \$198,939. At first, Directv did not operate as subscription television. However, to avoid generating controversy or unfair competition for the Colombian television channels, it soon became a subscription service (El Tiempo, October 7, 1996).

In 2000, the customer base was over 50,000 and the company's turnover increased 25\%. In 2001, Directv Colombia was capitalized with eight to 10 million dollars by Directv Latin America to support local operating costs (El Tiempo, May 9, 2001). In 2003, the Directv Group filed for bankruptcy, inasmuch as the decline in the price of Latin American currencies meant less income when converted to dollars. This sparked fear among subscribers, but Directv Latin America announced it would continue to operate and would inject USD \$ 300 million to put the company back on its feet and to make it profitable. Directv had 45,000 customers in Colombia at the time (El Tiempo, March 20, 2003).
By 2004, Directv Latin America had 1.5 million subscribers in 28 Latin American countries. It decided to sell a portion of the company to Darlene Investments, a subsidiary of the Cisneros Group from Venezuela. The Directv Group also purchased the share that remained in the hands of News Corp (a group belonging to British billionaire Rupert Murdoch) for USD \$ 579 million (Ibid).

Directv and Sky Colombia merged in June 2005, but kept the name Directv. The decision, endorsed by CNTV, respected customer interests. Approximately 350,000 decoders were purchased and three packages were offered: a basic package with 56 channels, a movie package with 63 channels and a premium package with 73 channels. Each package had a different cost. That same year, Directv had 77,351 users (Portafolio, February 26, 2004); by 2006, it had 94,249 customers, or $22 \%$ more than in 2005 . By June 2007, Directv Latin America had 2.94 million customers and revenue per customer was USD \$39.62. 2007 was definitely a year of growth for Directv (Portafolio August 17, 2007).

That same year, Directv, with 50\% more customers than in 2006, posted a $44 \%$ increase in earnings for the Directv Group and a 65\% increase in subscribers, thanks to a commercial strategy known as Directv Flexi (Portafolio, June 7, 2007). 2007 also was a year of partnerships. ETB (Empresa de Teléfonos de Bogotá, Bogota Telephony Company) and Directv teamed up to offer bundled Internet, telephone and television service to customers in Bogota, with a $27 \%$ increase in savings on the individual cost of these services (Portafolio, April 17, 2007). Later that year, Directv and Edatel partnered to offer the same three services in Valledupar (Cesar). When the Directv Group recovered, it purchased $14.1 \%$ of Darlene Investment's in 2007 for approximately USD \$ 325 million, the idea being to end and avoid any further legal disputes between the two companies. 
Volumen 13 Número 1 • Junio de 2010

In 2008, Directv Colombia allied with Emcali (Empresas Públicas de Cali) to offer Triple Play service, saving subscribers up to $13 \%$ on monthly charges. That year Directv had 177,756 users in Colombia. This figure increases daily, not only due to the advantages offered by Triple Play, but also because of the prepaid service launched that year (Portafolio, April 11, 2008).

By the end of 2009, there were 248,080 Directv subscribers in Colombia. The company launched its mobile telephone service, Control Plus, which enables customers to use their mobile telephones to schedule recordings of their favorite channels. Directv Plus DVR arrived in 2009 (a decoder that enables the customer to record, pause and rewind programming), along with Directv Plus HD (high definition channels). The latter implied an investment of USD \$ 20 million during 2008. With this new technology, local growth during the first half of the year came to $11 \%$, as opposed to the $3 \%$ drop experienced by the domestic market for subscription television (Portafolio, September 9, 2009).

During 2010, Directv will continue to consolidate its position as a leader in satellite content and service delivery. More than USD \$ 30 million will be invested to develop campaigns to encourage the public to subscribe to Directv in order to watch the 64 games of the 2010 World Cup in South Africa on HD between June and July of this year. Alliances also will be established with Sony and Adidas to generate higher sales and more advertising.

\section{The Major Mexican Share of the Pie}

The Mexican company Telmex was founded in 1947 by a group of Mexican entrepreneurs who purchased the Mexican branch of Sony Ericsson branch. In 1950, they acquired the Mexican branch of the ITT Corporation, thereby establishing a monopoly in the country's telephone service sector. In agreement with several other companies, pri- marily France Télécom and Southwestern Bell Corporation, Carlos Slim bought the firm and privatized it in 1990.

Telmex's entry into the Colombian market occurred in 2000, when Telmex Colombia S.A. was established. However, it did not begin operating until 2004, with the purchase of bankrupt AT\&T Latin America (El Tiempo, 2003). Telmex Colombia took over AT\&T Latin America's Internet provider services in the country, which accounted for approximately $1 \%$ of the market (Pragma, 2000).

Telmex's operations in Colombia during 2004 were limited to providing Internet services to corporate clients, specifically as a data center. In 2005, an agreement was signed that would have given Telmex $50 \%$ plus one share of Colombiana Telecomunicaciones-TELECOM (a government owned company) for USD $\$ 3.000$ million, which would have been used to cover TELECOM's pension liabilities and to implement a two-year investment plan to begin providing telecommunication services to a good portion of the country. However, the agreement was cancelled within a year, owing to objections from the Colombian Congress (Ministry of Information and Communication Technology, 2005).

In 2006, acquisition of $99.6 \%$ of the shares in the Colombian cable operator Superview, for USD \$37 million, established the company's clientele and gave it a stepping stone towards becoming the leading telecommunication service provider in the country. This purchase represented an increase of 138.205 subscribers, which is what Superview had in Bogotá (Galvis, A. CNTV. personal communication, April 14, 2010).

For Telmex, 2007 was a year of significant growth in Colombia. Its main acquisitions included the purchase of $100 \%$ of TVCable, a Colombian company, and its affiliate TVCable Comunica- 
Its practices in Colombia have been the subject of heated debate, given what appears to be a telecommunications monopoly being exerted by Slim and his companies, even if it is within the limits of the law.

ciones S.A. E.S.P., in addition to a $97.5 \%$ stake in Cablepacífico. Both companies were merged to become Telmex Hogar (Portafolio, 2007).

Telmex's acquisitions during 2007 also included Cablecentro, a cable operator purchased for USD\$345 million, Megainvest Ltda., a cable content producer, which added content production to the company's portfolio, Comunicaciones Ver $\mathrm{TV}$, S.A. a cable programming magazine, thereby diversifying Telmex's interest in the telecommunications sector, and $100 \%$ of Satelcaribe, purchased for USD\$51 million. These companies were merged to become Telmex Colombia S.A. and the acquisition gave Telmex $51 \%$ of the cable television market in Colombia by the end of 2007, as well as a share of the market for content production.

In 2008, Telmex purchased $100 \%$ of Teledinámica for USD\$31 million. This concluded the acquisition and merger of existing cable operators in Colombia, thus completely absorbing any possible competitor in the cable pay TV market and rounding out its offer of Triple Play services, including Internet, IP Telephone, Cable TV. Telmex also launched international call services through the 456 prefix and entered the content production market with the publication of a cable listing magazine known as Páginas Telmex (a yellow page directory for the city of Cali) and the production of content for its own cable channels (Telmex, 2000 to 2009).

By the end of 2008 Telmex had several subsidiaries in Colombia; namely, $100 \%$ of Telmex
Colombia S.A., $99.6 \%$ of Superview Telecomunicaciones S.A., $100 \%$ of Telmex Hogar S.A., $100 \%$ of TV Cable Telecomunicaciones S.A., $100 \%$ of Network and Operations S.A., $100 \%$ of The Now Operation S.A., $100 \%$ of Megacanales S.A. and $100 \%$ of Cablecaribe S.A. All Telmex services in Colombia are provided through these companies; that is, cable television, landlines, Internet services, long distance calling and content production.

During 2009, in a final move, Telmex Hogar was absorbed by Telmex Colombia S.A. The accounts and operations of these companies were integrated to unify brands and to reduce operating costs as a way to avert crisis. Nowadays, Telmex is the leading telecommunication service provider in Colombia, with $58 \%$ of the country's cable television market. It also offers Triple Play services and content production (Dinero, 2009).

Telmex has established itself in the Colombian market as a leader in the telecommunications sector, providing services than involve Triple Play and content production for added value. Its practices in Colombia have been the subject of heated debate, given what appears to be a telecommunications monopoly being exerted by Slim and his companies, even if it is within the limits of the law.

\section{Telmex and the Colombian Mobile Telephone Industry}

América Móvil was created by Carlos Slim in 2000 as a branch of Telmex. Originally an affiliate, the company became independent in 2001 and has developed into an even larger telecommunications enterprise. It entered the Colombian market in 2002 with the restructuring of Telecom Americas, which gave América Móvil a 77.1\% stake in Comunicación Celular Comcel S.A., the leading mobile telephone company in Colombia at the time. 
Acquisition of $100 \%$ of the shares of two other mobile telephone operators in Colombia: Occel and Celcaribe, gave the company an important segment of the market and coverage throughout much of the region. (America Móvil Annual Reports, 2000 to 2009).

As of 2003, América Móvil's investments and transactions in Colombia have been dedicated to acquiring and merging with other local firms and expanding the company's growth in terms of its subscriber base and investment in infrastructure to develop facilities, such as the GSM and 3GS networks for the company's operation. Since 2003 América Móvil's subscriber base has increased by no less than $50 \%$ a year and its earnings have been used to develop new networks and technology designed to maintain the company's leadership in Colombia as a mobile telephone operator.

For América Móvil, the Colombian subsidiary operating under the brand name Comcel is the third most profitable for the firm and confirms the potential of the Colombian market for telecommunication services. Currently, Comcel has over $64 \%$ of the mobile telephone market in the country, followed by Telefónica with its brand name Movistar, which has $24.5 \%$ of the market. Luxemburg-based Millicom ranks third.

As for 2010, there are plans to merge Telmex and América Móvil, both of which are owned by Carlos Slim. If this occurs, the new company will take the lead in the Latin American market, through the offer of quadruple play services that combine broadband, television, voice and mobile telephone service (El Tiempo, 2010).

The Spanish firm Telefónica ranks second in the telephone market in Colombia. Currently the third largest landline service provider in the world, it acquired $50 \%$ plus one share of the state-owned Colombia Telecomunicaciones (Telecom) in 2006. Prior to that acquisition, Telefónica had begun to explore the Colombian market in 1999 through the purchase of Telecomunicaciones Ganaderas S.A., Terra Networks and consolidation of the firm Telefónica Data Colombia S.A.

In 2000, Telefónica entered the Colombian market for Internet services under the name Terra Networks Colombia Holdings S.A., and complemented this move by acquiring the Internet portal Laciudad.com for US\$20 million.

During the same year, Telefónica fully established its operations in the telecommunications market with the purchase and merger of Rey Moreno, S.A. and Telecomunicaciones Ganaderas S.A. Atento Colombia S.A. was established in 2000 to supply data to meet the needs of corporate clients.

In 2004, Telefónica acquired 100\% of Telefónica Móviles Colombia, S.A. for a total of USD $\$ 1.050$ billion. And, by 2005, the merger between Colombia Telecom, which was renamed Telefónica Telecom earlier that year, and Telefónica Empresas Colombia proved to be an accurate strategy for increasing the number of subscribers and improving profits (Telefónica, 2000 to 2009).

Telefónica launched its triple play services in Colombia during 2007, with the development of a satellite television product, in addition to the voice and broadband services that had been operating since 2004. In all, these services are known as "Trio Telefónica". 2007 was an important year for the company.

Telefónica's final acquisition to date was in 2008, when it purchased $40.5 \%$ of Telefactoring Colombia, S.A. Although established, the company had yet to being operating by the end of 2009. A consolidation strategy was initiated that same year, whereby one of Telefónica's own companies, Colombia Telecom, S.A., absorbed Telefónica Data Colombia, S.A. 
2009 was a year of setbacks for Telefónica. The European Commission ordered the company to integrate all its brands and firms under the name of either Movistar or Orange. This order will be carried out by the end of 2010 .

The third participant in the telephone industry in Colombia is the firm Colombia Móvil Tigo, which is $51 \%$ owned by the Luxemburg-based firm Millicom. The TIGO brand replaced OLA, since Millicom purchased the majority of the company's shares in 2006. It now occupies third place, following América Móvil's brand Comcel and Telefónica's Movistar.

Millicom provides telephone services to fourteen countries in Africa and America. It also is associated with different local firms in each country, so as to offer cable television services to its subscribers. Millicom's performance in the Colombian market has been highly publicized in the country's media, inasmuch as it joined forces with the Bogotá-based firm Empresa de Teléfonos de Bogotá (ETB) and the Medellínbased Empresas Publicas de Medellín (EPM).

This overview of the market where two types of companies thrive; namely, service providers and mixed companies that provide both content and services, shows a tendency towards growth and development in new and long-standing duopolies involving companies with foreign capital. The telecommunications market has been very profitable for these firms and has allowed them to grow and establish themselves in the country.

\section{Conclusions}

In Colombia, the first decade of the $21^{\text {st }}$ century witnessed the penetration of a significant amount of foreign capital in the field of media and telecommunications providers. Nowadays, an important segment of these sectors relies on international firms and investors, who continue to regard Co- lombia as a stable and growing market, not only in terms of consumers, but also with respect to fair practices and positive regulatory conditions that stimulate the inflow of foreign capital. Graphics 3 and 4 compare the growing evolution of FDI in Colombian media sectors between 1999 and 2009 (See graphics 3 and 4).

A good example is the battle over the license for the third private national television channel. It is being waged by international media groups, particularly Planeta, and their Colombian associates, who play a very secondary role, but only because Colombian regulations limit foreign investment in a commercial television channel to $40 \%$. Most of the financing will come from abroad.

\section{Graphic 3}

\section{Foreign Direct Investment in Colombian media 1999}

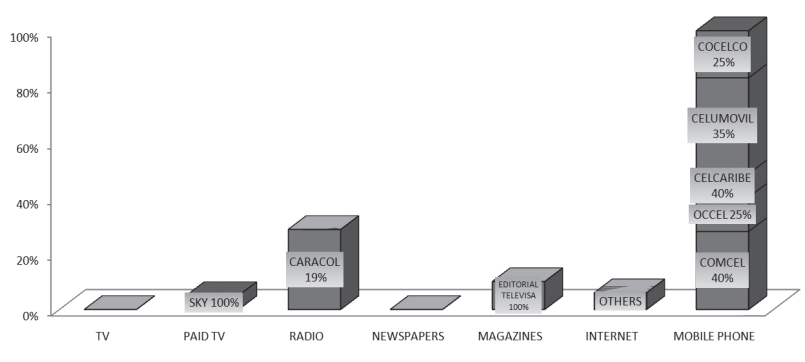

Graphic 4
Foreign Direct Investment in Colombian media 2009

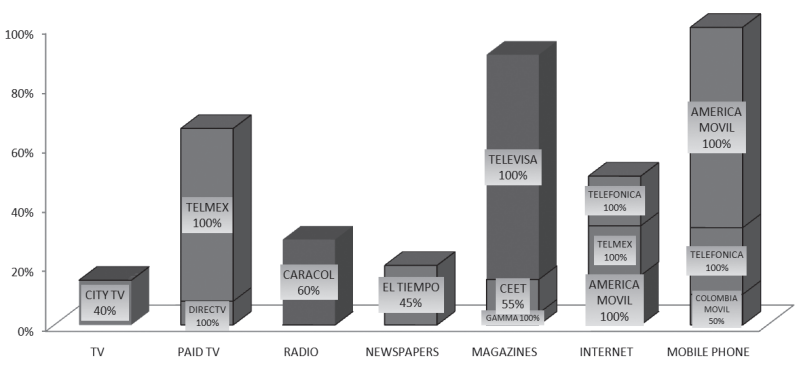


Despite this situation, the traditional Colombian media groups continue to control an important share of the media market. The Santodomingo Group still owns Caracol Television, a national private channel; its international brand, Caracol International; El Espectador, a daily newspaper; and several weekly magazines, the most important being Cromos.

The Ardila Lulle Organization controls RCN Television, a national private channel, its international NTN24 news brand, the RCN Radio network and Sonolux, an audio recording and entertainment firm. Publicaciones Semana (owned by the López family) is the leader in the magazines industry. Smaller media firms specialized in radio and print survive, but their options are becoming increasingly limited.

International media firms will continue their bid to grow and consolidate a major share of the media market in Colombia. This poses a challenge to the Colombian government in terms of ensuring fair practices and avoiding monopolistic control. These are important to and relevant issues for future inquiries and academic research.

\section{References}

America Movil (2000 to 2009). Annual Report. Retrieved April 13, 2010 from URL: http:// www.americamovil.com/index_eng.htm

Arango, G. et al. (2009). The Media in Colombia. In Albarran, A. (ed). The Handbook of Spanish Language Media. New York: Routledge.

Asociación Colombiana de Investigación de Medios (ACIM). (December 2009). Estudio General de Medios (EGM), Ola 2009-II. Bogotá: ACIM.

Asomedios (2010). Reseña histórica de revistas. Retrieved March 112010 from URL: http:// www.asomedios.com/Asomedios/paginas/documento.aspx?idr=1595.
Caracol Radio (December 10, 2009). In 2010, foreign investment in Colombia will amount to 10 billion dollars. Retrieved from URL: http:// www.caracol.com.co/nota.aspx?id=922769.

Comisión Nacional de Televisión (CNTV) (June 2008). Directorio de Operadores. Bogotá: CNTV.

Consejo Latinoamericano de Publicidad en Multicanales (LAMAC). (2009). Penetración de TV Paga, Latinoamérica. Retrieved March 2, 2010 from URL: http://www.lamac.org/Espa\%c3\%b1ol/ Investigaci $\%$ c3\%b3n/Penetraci $\%$ c3 $\%$ b3n/ Penetraci\%c3\%b3n_de_TV_de_Paga/Latinoam \%c3\%a9rica/

Departamento Administrativo Nacional de Estadística (DANE) (2009). Uso y penetración de tecnologías de la información y la comunicación (TIC) en hogares y personas. Retrieved April 2, 2010 from URL: http://www.asocel.org. co/pdf/tic.pdf

Departamento Administrativo Nacional de Estadística (DANE) (2005). Censo Nacional 2005 Nivel Nacional. Dirección de Difusión, Mercadeo y Cultura Estadística. Bogotá. DANE.

Dinero (March 4, 2009). La fusión de Telmex. Retrieved April 13, 2010 from URL: http://www. dinero.com/negocios/fusion-telmex_58437.aspx

Dinero (March 28, 2008). Negocios-Prisa quiere a Caracol TV. Retrieved March 22, 2010 from URL: http://www.dinero.com/edicion-impresa/ negocios/prisa-quiere-caracol-tv_46091.aspx

Dinero (August 3, 2007). El comienzo de una nueva era. Retrieved March 22, 2010 from URL: http://www.dinero.com/negocios/comienzonueva_37437.aspx

Dinero (August 1, 2007). Planeta se queda con el 40\% de City TV. Retrieved March 22, 2010 from 
URL: http://www.dinero.com/on-line/planetaqueda-40-citytv_37399.aspx

DIRECTV (2009). Who are we. Retrieved March 22, 2010 from http://www.directv.com/DTVAPP/global/contentPage.jsp?assetId=3580002

Economic Commission for Latin America and the Caribbean (ECLAC) (2009). Statistical Yearbook for Latin American and the Caribbean. Santiago de Chile: ECLAC.

El Tiempo (February18, 2010) ATET Latin America yaes de Telmex. Retrieved April 13, 2010 from URL: http://www.eltiempo.com/enter/actualidad_a/ ARTICULO-PRINTER_FRIENDLY-PLANTILLA_PRINTER_FRIENDL-7238334.html

El Tiempo (April 1, 2010). Inversión extranjera cayó más de lo que se esperaba. p. 1-9.

El Tiempo (August 24, 2009). IBN compraría el 4,5\% del Grupo Prisa. Retrieved March 22, 2010 from http://www.eltiempo.com/archivo/documento/MAM-3583977

El Tiempo (March 8, 2008). Año de buen crecimiento en Casa Editorial El Tiempo. Retrieved March 22, 2010 from URL: http://www.eltiempo.com/archivo/documento/MAM-2855092

El Tiempo (August 15, 2007). Directv celebra 10 años y completa 115.000 abonados. Retrieved March 22, 2010 from URL: http://www.eltiempo.com/archivo/documento/MAM-2618901

El Tiempo (May 4, 2005). Grupo Prisa y El Tiempo firman alianza de negocios. Retrieved March 22, 2010 from URL: http://www.eltiempo.com/ archivo/ documento/MAM-1678574

El Tiempo (November 5, 2003). ATET Latin America ya es de Telmex. Retrieved April 13, 2010 from URL: http://www.eltiempo.com/archivo/ documento/MAM-1001314
El Tiempo (March 20, 2003). Directv: Todo normal en Colombia. Retrieved on March 22, 2010 from URL: http://www.eltiempo.com/archivo/ documento/MAM-982604

El Tiempo (May 9, 2001). Inyección de capital para Directv Colombia. Retrieved March 22, 2010 from URL: http://www.eltiempo.com/archivo/documento/MAM-522844.

El Tiempo (October 7, 1996). La CNTV autoriza a Directv. El Tiempo. Retrieved March 22, 2010 from URL: http://www.eltiempo.com/archivo/ documento/MAM-527713

Grupo Cisneros (2007-09). La Organización Cisneros. Retrieved March 22, 2010 from http:// www.cisneros.com/Organizacion

Grupo Planeta (2001). Tradición y visión del futuro. Retrieved March 22, 2010 from URL: http:// www.planeta.es/esp/asp/info_corporativa.html:

Grupo Prisa (2008). Prisa, Un grupo Global. PRISA. Retrieved March 22, 2010 from URL: http://www.prisa.com/quienes-somos/

Herman E. \& McChesney R. (1997). Los medios globales, los nuevos misioneros del capitalismo corporativo. Madrid: Ediciones Cátedra.

International Monetary Fund (1994). Balance of Payments Manual (5 ${ }^{\text {th }}$ Edition), p. 86 Retrieved from URL: http://www.imf.org/external/np/sta/ bop/bopman.pdf

Latin Trade (English) (2009). Colombia, a Safe Destination for Investment. 17 (2), 52.

Mastrini, G. \& Becerra, M. (2007). Presente y tendencias de la concentración de medios en América Latina. Revista ZER, 22, p.15-40

Milenio (January 2, 2010). Mantiene México creciente flujo de inversión en Colombia. Retrieved 
from URL: Milenio URL: http://www.milenio. com/node/351991

Millicom. Annual Reports 2000 to 2009. Retrieved April 13, 2010 from URL: http://www.millicom. com/investors/annuals.cfm

Ministerio de Tecnologías de la Información y las Comunicaciones (August 25, 2005). Principio de acuerdo entre TELECOM y Telmex. Retrieved April 13, 2010 from URL: http://www.mintic. gov.co/mincom/faces/index.jsp?id=5286

Ministry of Commerce, Industry and Tourism \& Invest in Colombia Program (2009). Industria BPO\&O en Colombia. [Power Point slides]. Retrieved from URL: Invierta En Colombia URL: http://www.inviertaencolombia.com.co/Adjuntos/068_Sector\%20BPO\&O.pdf

Ministry of Commerce, Industry and Tourism \& Proexport (2009). Reporte IED en Colombia según balanza de pagos y balanza cambiaria 2010. [Power Point slides]. Retrieved from URL: Proexport URL: http://www.proexport.gov. co/vbecontent/library/documents/DocNewsNo9976DocumentNo8916.pdf

Portafolio (February 10, 2010). Vuelve a crecer la inversión extranjera en Colombia. Retrieved from URL: http://www.Portafolio.com.co/economia/economiahoy/ARTICULO-WEB-NOTA_ INTERIOR_PORTA-7310131.html.

Portafolio (September 9, 2009). Directv con Control Plus. Retrieved March 22, 2010 from URL: http://www.eltiempo.com/archivo/documento/ MAM-3611837

Portafolio (March 5, 2010). Grupo Prisa acoge en su capital a firma estadounidense Liberty Acquisition. Retrieved March 22, 2010 from URL: http://www.eltiempo.com/archivo/documento/ CMS-7353432
Portafolio (May 15, 2009). Grupo Cisneros Producirá en Colombia. Retrieved March 22, 2010 from URL: http://www.dinero.com/negocios/ grupo-cisneros-producira-colombia_59638.aspx

Portafolio (April 11, 2008). Alianza entre Emcali y Directv para ofrecer el triple play. Retrieved March 22, 2010 from URL: http://www.eltiempo.com/archivo/documento/CMS-4094215

Portafolio (September 18, 2008). Nace en Colombia nueva empresa comercializadora de publicidad para acceder a los consumidores. Retrieved March 22, 2010 from URL: http://www.eltiempo.com/archivo/documento/CMS-4245786

Portafolio (August 17, 2007). Directv Latino va rumbo a los tres millones de clientes. Retrieved March 22, 2010 from URL: http://www.eltiempo.com/archivo/documento/MAM-2618901

Portafolio (April 17, 2007). ETB y Directv estrechan su alianza. Retrieved March 22, 2010 from URL: http://www.eltiempo.com/archivo/documento/MAM-2453113Portafolio (2007, June 7)

Portafolio (June 26, 2007). Se enredan compras de Telmex. Retrieved April 13, 2010 from URL: http://www.eltiempo.com/archivo/documento/ MAM-2547195

Portafolio (August 24, 2006). Telmex se queda con Superview. Retrieved April 13, 2010 from URL: http://www.eltiempo.com/archivo/documento/MAM-2148537

Portafolio (February 26, 2004). Sky y Directv se Fusionan. Retrieved March 22, 2010 from URL: http://www.eltiempo.com/archivo/documento/ MAM-1568022

Portafolio (May 19, 2003). Bajón en utilidades de Prisa. Retrieved March 22, 2010 from URL: http://www.eltiempo.com/archivo/documento/ MAM-970747 
Pragma (2000). America Latina y Colombia: Resultados y tendencias de Internet, comercio electrónico y Net Economy. Retrieved April 13, 2010 from URL: http://www.pragma.com.co/pragmagazin/1999-10/cifrasLatinoPrint.html

Proexport Colombia (2009). Informe de Exportaciones, Inversión Extranjera y Turismo México. Dirección de Información Comercial - Proexport Colombia. Retrieved from URL: http://wwww. proexport.com.co/vbecontent/library/documents/ DocNewsNo10394DocumentNo8499.pdf

Research and Markets (2009). News and Magazine in Colombia to 2013. Annual Report. Datamonitor.

Revista Semana (May 2, 2009). Arremetida azteca. Retrieved from URL: http://www.semana.com/ noticias-economia/arremetida-azteca/123464.aspx

Revista Semana (May 2, 2009). Los nuevos conquistadores. Retrieved from URL: http://www. semana.com/noticias-economia/nuevos-conquistadores/123466.aspx

Roetter, Martin (2009). Mobile broadband, competition and spectrums caps. Retrieved March 18, 2010 from: http://www.asocel.org.co/pdf/ Spectrum_Caps_Report.pdf

Rueda, C. (April 19, 2002). La Estrategia de Caracol. El Tiempo. Retrieved March 22, 2010 from URL: http://www.eltiempo.com/archivo/documento/MAM-1373362
Sierra, L. (September 18, 2007). 'La decisión editorial la tomarán los colombianos', dice Presidente de Grupo Planeta sobre EL TIEMPO. El Tiempo. Retrieved March 22, 2010 from URL: http://www.eltiempo.com/archivo/documento/ CMS-3726862

Sinclair, J. (2000). Televisión, comunicación global y regionalización. Barcelona: Editorial Gedisa.

Telefónica. Annual Reports 2000 to 2009. Retrieved April 13, 2010 from URL: http://www. Telefónica.com/en/shareholders_investors/ html/financyreg/informesanuales.shtml

Telmex. Financial Reports 2000 to 2009. Retrieved April 13, 2010 from URL: http://www.telmex. com/mx/corporativo/relacionInver_en_reporteFinan.jsp

Téllez, D., Bohórquez, L., \& Godoy, J. (2009). Foreign Direct Investment in Latin America and its Effects over Development 1990-2006. In Journal of Economics \& Management, 5, 106. Retrieved from URL: URL: Business Source Complete database

United Nations Conference on Trade and Development (2010). Inversión Extranjera Directa (IED). Retrieved from URL: http://www.unctad.org/ Templates/StartPage.asp?intItemID=2527\&lang=3

Universidad del Rosario (2006). Tendencias actuales de la inversión extranjera en Colombia. Programa de Promoción Científica, 1, p. 8. 